\title{
Analisa Kinerja Solar Tracker dengan Menggunakan Solar Cell Berbasis Arduino UNO
}

\author{
Putri Pertiwi Wanajaya ${ }^{1}$ \\ ${ }^{1}$ Prodi Teknik Elektro UNPAM \\ Jln. Puspiptek Raya No 46 Buaran, Setu - Tangerang Selatan 15310 \\ wanajaya.putri@gmail.com
}

\begin{abstract}
ABSTRAK
Pengembangan dan penggunaan energi terbarukan merupakan kebutuhan penting di masa depan demi meminimalisir emisi karbon dan untuk membatasi perubahan suhu rata-rata global. Energi terbarukan yang dapat digunakan salah satunya adalah energi surya. Pemanfaatan energi matahari ini dapat dilakukan melalui energi listrik yaitu menggunakan teknologi dengan Solar Cell. Sel surya atau solar cell dapat mengkonversi energi cahaya matahari menjadi energi listrik. Salah satu kendala dalam konversi energi surya adalah kurang optimalnya penerimaan energi matahari akibat penempatan solar cell yang hanya menghadap satu arah saja atau bersifat statis. Maka dari itu, perlu dibuatnya suatu sistem yang dapat memodifikasi solar cell selalu mengikuti arah bergeraknya cahaya matahari. Energi yang dihasilkan dari solar cell akan maksimal apabila solar tracker selalu tegak lurus terhadap arah datangnya sinar matahari. Pada alat ini dibuat solar tracker menggunakan mikrokontroler Arduino Uno dalam mengendalikan pergerakan dari motor servo, motor stepper dan sensor LDR dalam mengikuti pergerakan cahaya matahari. Hasil analisa menunjukkan bahwa daya yang diperoleh Solar Panel yang mengikuti pergerakan cahaya matahari (Solar Tracker) lebih besar dibandingkan dengan Solar Panel pada posisi tetap. Produksi energi pada sistem dinamis dengan menggunakan servo 33\% lebih besar dibandingkan dengan statis, sedangkan yang menggunakan stepper $36 \%$ lebih besar daripada solar cell dengan kondisi statis.
\end{abstract}

Kata kunci: Solar Tracker, Solar Cell, LDR dan Arduino Uno R3.

\begin{abstract}
ANAL YZE SOLAR TRACKER PERFORMANCE USING SOLAR CELL BASED ON ARDUINO UNO R3 Development and uses of renewable energy is one of the most important needs in the future to reduce carbon emissions and limit global average temperature changes. Renewable energy that can be use one of them is solar energy. Indonesia, which is in the equatorial region, has considerable solar energy potential throughout the year. Solar energy is very potential to be utilized directly as an alternative energy source. Utilization of solar energy can be done through electrical energy that is using technology with solar cells. Solar cells can convert solar light energy into electricity. One of the obstacles in solar energy conversion is less optimal solar energy reception due to the placement of solar cells that only facing one direction only or static. Therefore, it is necessary to create a system that can make the solar cell always follow the direction of the movement of the sun. Solar cell as a solar energy catcher then assembled into a solar tracker. The energy generated from the solar cell will be maximized if the solar tracker is always perpendicular to the direction of the focus of the coming of the sun. In other words, the solar cell must follow the direction of the movement of sunlight. For this reason, this solar tracker uses Arduino Uno microcontroller in controlling the movement of servo motor, stepper motor and LDR sensor in following the movement of sunlight. The results show that the power obtained by Solar Panel following the solar light (Solar Tracker) is bigger than Solar Panel in fixed position. Production of energy in dynamic systems using servo $33 \%$ greater than static, while using stepper $36 \%$ greater than solar cell with static condition.
\end{abstract}

Key words: Solar Tracker, Solar Cell and Arduino Uno R3. 


\section{PENDAHULUAN}

Cahaya matahari dapat dikembangkan dengan cara membuat rangkaian alat yang digunakan untuk mengkonversi energi cahaya matahari menjadi energi listrik. Rangkaian alat yang dapat digunakan salah satunya adalah solar cell.

Permasalahannya saat ini adalah bagaimana menggunakan solar cell untuk menghasilkan output listrik yang maksimum atau optimal. Dengan posisi panel menghadap ke atas atau solar cell yang bersifat statis dan jika panel dianggap benda yang mempunyai permukaan rata maka solar cell akan mendapat radiasi matahari maksimum pada saat matahari tegak lurus dengan dua bidang panel. Hal ini menyebabkan penerimaan energi cahaya matahari tidak maksimum atau optimal. Oleh karena itu, perlu dibuatnya suatu sistem atau alat yang dapat memodifikasi solar cell selalu mengikuti arah pergerakan cahaya matahari.

Maka prototipe alat ini menggunakan mikrokontroler Arduino Uno dalam mengendalikan pergerakan dari motor servo, motor stepper dan sensor LDR mengikuti pergerakan cahaya matahari. Pada penelitian ini akan membandingkan efisiensi penggunaan solar cell yang menghadap satu arah serta solar cell yang selalu mengikuti arah bergeraknya cahaya matahari menggunakan servo dan stepper motor dari segi tegangan, daya dan intensitas cahaya.

\section{TEORI}

\section{Solari Meter}

Alat yang digunakan untuk mengukur radiasi cahaya matahari total.

\section{Lux Meter}

Lux meter adalah alat untuk mengukur besarnya intensitas cahaya. Diperlukannya sensor yang peka dan linier agar dapat mengetahui besarnya intensitas cahaya yang didapatkan. Intensitas cahaya akan berkutang jika jaraknya semakin jauh.

\section{Arduino Uno R3}

Arduino Uno memiliki empat belas kaki digital masukan atau keluaran, dimana ada enam kaki-kaki digital diantaranya yang digunakan sebagai sinyal PWM (Pulse Width Modulation). PWM signal itu sendiri berfungsi sebagai pengatur kecepatan perputaran motor. Arduino Uno juga memiliki enam kaki-kaki analog masukan, crystal ocilator yang kecepatannya mencapai $16 \mathrm{MHz}$, selanjutnya memiliki sebuah koneksi USB.

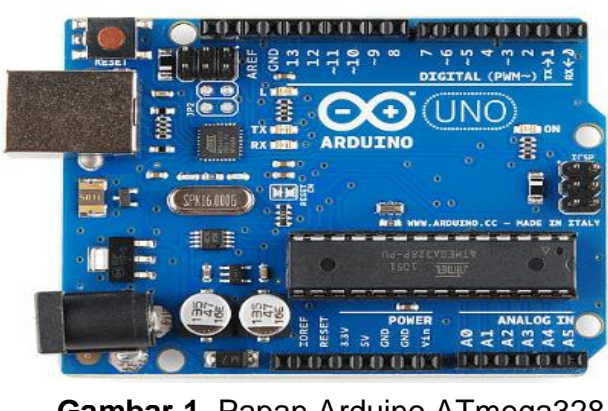

Gambar 1. Papan Arduino ATmega328

\section{Solar Cell}

Solar Cell terbuat dari bahan semi konduktor. Salah satu bahan solar cell adalah crystal silicon (c-Si). Sel surya merupakan salah satu jenis sensor cahaya yaitu photovoltaic. Apabila sel surya menerima cahaya maka pada masing-masing kaki sel surya akan muncul tegangan sebesar 0,5 Vdc - 0,6 Vdc untuk setiap selnya. Tegangan yang didapatkan sebanding dengan intensitas cahaya matahari yang mengenai permukaan sel surya.

\section{METODOLOGI}

\section{Mekanik Prototipe}

Prototipe solar tracker ini menggunakan motor servo dan motor stepper sebagai penggerak. Pada prototipe ini, solar cell dalam keadaan statis diarahkan ke Timur dengan kemiringan $15^{\circ}$, dan pada posisi dinamis dihadapkan ke arah Timur, lalu prototipe mengikuti cahaya matahari sampai ke Barat.

\section{Perencanaan Alat}

Sebuah tracker surya adalah sebuah alat mekanik yang bekerja dengan mengikuti matahari. Ada dua jenis mekanisme yang paling umum digunakan yaitu pelacak aktif dan pelacak pasif. Pelacak aktif diarahkan 
ke matahari dengan sirkuit listrik. Motor servo atau motor stepper kemudian digunakan untuk mengarahkan pelacak seperti yang diperintahkan oleh mikrokontroler Arduino Uno R3 dan LDR sensor ke arah cahaya matahari. Pelacak aktif mengandung komponen listrik. Pelacak pasif menggunakan mekanisme hidrolik yang merespon cahaya matahari.

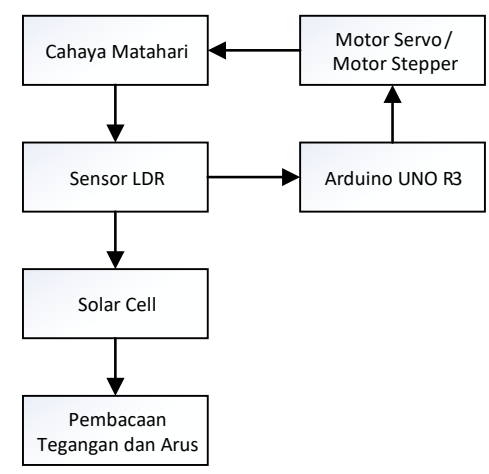

Gambar 2. Rancangan Sistem

\section{Perancangan Flowchart}

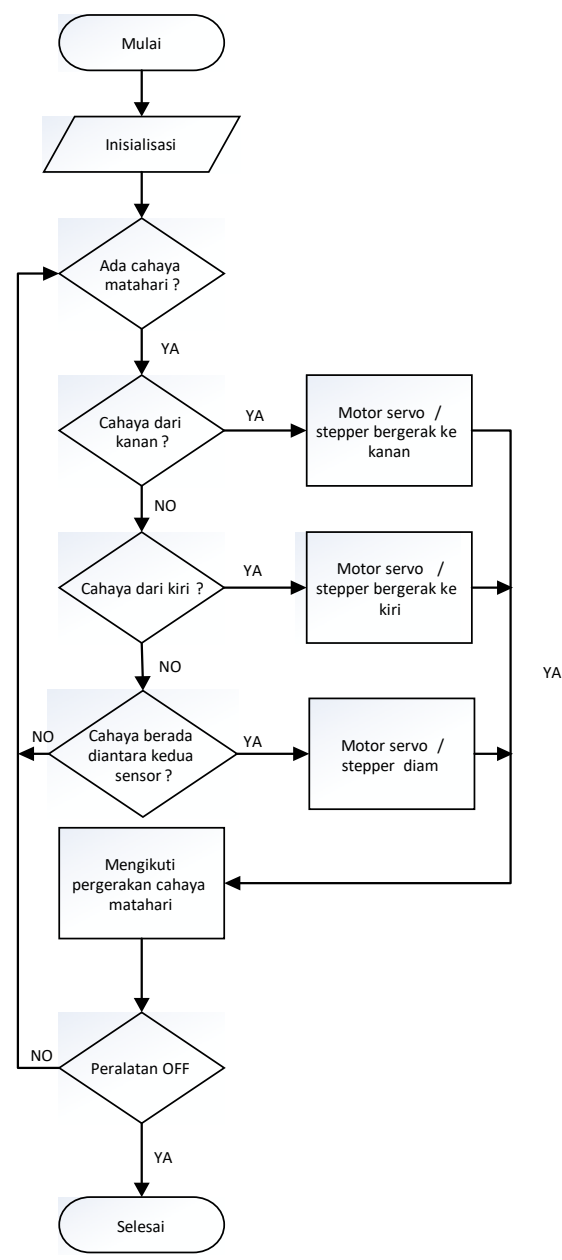

Gambar 3. Flowchart
Dapat dilihat dari gambar 3 urutan program yang akan dijalankan, yaitu awal mula menekan push button untuk menghidupkan rangkaian, lalu mikrokontroler Arduino Uno mulai menginisialisasi input. Ketika cahaya matahari diberikan, sensor LDR menangkap cahaya tersebut, lalu mikrokontroler Arduino Uno memberi perintah kepada motor servo atau stepper untuk mengikuti sumber cahaya yang diberikan. Jika sumber cahaya matahari tiruan datang dari sebelah kanan maka motor akan bergerak ke kanan mengikuti sumber cahaya, jika cahaya datang dari sebelah kiri, motor servo atau stepper akan bergerak mengikuti cahaya matahari tiruan ke sebelah kiri. Namun, jika cahaya mengenai kedua sensor, motor servo atau stepper akan diam dan mikrokontroler Arduino Uno akan melihat sensor mana yang lebih banyak terkena cahaya, jadi motor servo atau stepper dapat mengikuti cahaya matahari itu kembali. Lalu Solar Cell mengubah energi cahaya menjadi tegangan dan dapat di ukur menggunakan AVO meter.

\section{HASIL DAN PEMBAHASAN}

\section{Perbandingan Solar Panel Statis dan Motor Servo}

Tabel 1. Pengukuran Solar Panel Statis dan Dinamis (Servo)

\begin{tabular}{|c|c|c|c|c|c|c|}
\hline \multirow{2}{*}{$\begin{array}{c}\text { Waktu/15 } \\
\text { Menit } \\
\text { (HH.MM) }\end{array}$} & \multicolumn{2}{|c|}{$\mathbf{V}_{\mathbf{m p}}$ (Volt) } & \multicolumn{2}{c|}{$\mathbf{I}_{\mathbf{m p}}$ (Ampere) } & \multicolumn{2}{c|}{$\mathbf{P}_{\max }$ (Watt) } \\
\cline { 2 - 7 } & Statis & Servo & Statis & Servo & Statis & Servo \\
\hline $6: 00$ & 0.025 & 0.0275 & 0.015 & 0.02 & 0.00045 & 0.00055 \\
\hline $7: 00$ & 1.34 & 1.55 & 0.19 & 0.215 & 0.3687 & 0.52675 \\
\hline $8: 00$ & 4.3725 & 5.325 & 0.4425 & 0.4925 & 1.95825 & 2.65525 \\
\hline $9: 00$ & 6.6275 & 6.8375 & 0.595 & 0.6125 & 4.027175 & 4.2169 \\
\hline $10: 00$ & 7.365 & 7.5025 & 0.6875 & 0.68 & 5.06315 & 5.1017 \\
\hline $11: 00$ & 5 & 4.9 & 0.63 & 0.4925 & 3.14975 & 2.41175 \\
\hline $12: 00$ & 6.67 & 7.5625 & 0.5825 & 0.585 & 3.870025 & 4.482375 \\
\hline $13: 00$ & 4.82 & 6.5575 & 0.455 & 0.555 & 2.277 & 3.70625 \\
\hline $14: 00$ & 2.545 & 5.52 & 0.325 & 0.5075 & 0.881925 & 2.80335 \\
\hline $15: 00$ & 1.045 & 5.2425 & 0.2375 & 0.4675 & 0.2636 & 2.451575 \\
\hline $16: 00$ & 0.297 & 2.2825 & 0.1075 & 0.1775 & 0.05988 & 0.624235 \\
\hline $17: 00$ & 0.1094 & 0.8985 & 0.0635 & 0.1055 & 0.015156 & 0.195267 \\
\hline $\begin{array}{c}\text { Average / } \\
\text { Day }\end{array}$ & $\mathbf{3 . 3 5}$ & $\mathbf{4 . 5 2}$ & $\mathbf{0 . 3 6}$ & $\mathbf{0 . 4 1}$ & $\mathbf{1 . 8 3}$ & $\mathbf{2 . 4 3}$ \\
\hline Wh/ Day & & & & $\mathbf{2 1 . 9 4}$ & $\mathbf{2 9 . 1 8}$ \\
\hline
\end{tabular}


PERBANDINGAN STATIS DENGAN SERVO

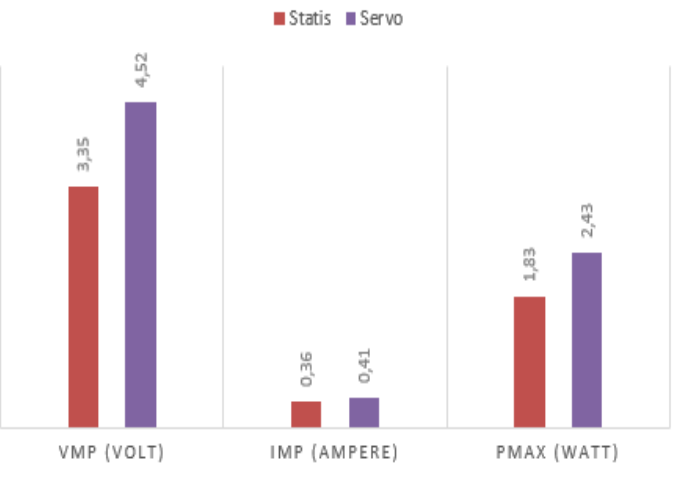

Gambar 4. Perbandingan Solar Panel statis dengan dinamis (Servo)

Dari grafik pada gambar 4 dapat dilihat besar tegangan yang didapatkan oleh solar panel pada posisi tetap lebih kecil bila dibandingkan oleh perolehan solar panel pada posisi mengikuti gerak matahari, dari hasil perhitungan diperoleh rata rata nilai $V_{m p}$ untuk posisi tetap adalah sebesar 3,35 Volt, $I_{m p}$ 0,36 A, $P_{\max }$ 1,83 watt sedangkan pada posisi tracker menggunakan servo adalah sebesar 4,52 Volt, $I_{m p} 0,41 \mathrm{~A}, P_{\max } 2,43$ watt. Energi pada sistem dinamis (Servo) $33 \%$ lebih besar daripada statis.

\section{Perbandingan Solar Panel Statis dan Motor Stepper}

Tabel 2. Pengukuran Solar Panel Statis dan Dinamis (Stepper)

\begin{tabular}{|c|c|c|c|c|c|c|}
\hline \multirow{2}{*}{$\begin{array}{c}\text { Waktu/15 } \\
\text { Menit } \\
\text { (HH.MM) }\end{array}$} & \multicolumn{2}{|c|}{$\mathbf{V}_{\text {mp }}$ (Volt) } & \multicolumn{2}{|c|}{$\mathbf{I}_{\text {mp }}$ (Ampere) } & \multicolumn{2}{c|}{$\mathbf{P}_{\max }$ (Watt) } \\
\cline { 2 - 7 } & Statis & Stepper & Statis & Stepper & Statis & Stepper \\
\hline $6: 00$ & 0.025 & 0.04 & 0.015 & 0.03 & 0.00045 & 0.0013 \\
\hline $7: 00$ & 1.34 & 1.5675 & 0.19 & 0.215 & 0.3687 & 0.52575 \\
\hline $8: 00$ & 4.3725 & 5.4 & 0.4425 & 0.505 & 1.95825 & 2.7535 \\
\hline $9: 00$ & 6.6275 & 6.8575 & 0.595 & 0.6275 & 4.027175 & 4.32885 \\
\hline $10: 00$ & 7.365 & 7.51 & 0.6875 & 0.685 & 5.06315 & 5.14455 \\
\hline $11: 00$ & 5 & 5.075 & 0.63 & 0.5 & 3.14975 & 2.5375 \\
\hline $12: 00$ & 6.67 & 7.625 & 0.5825 & 0.59 & 3.870025 & 4.55525 \\
\hline $13: 00$ & 4.82 & 6.5525 & 0.455 & 0.5725 & 2.277 & 3.825575 \\
\hline $14: 00$ & 2.545 & 5.545 & 0.325 & 0.51 & 0.881925 & 2.82805 \\
\hline $15: 00$ & 1.045 & 5.26 & 0.2375 & 0.4775 & 0.2636 & 2.512 \\
\hline $16: 00$ & 0.297 & 2.3 & 0.1075 & 0.1815 & 0.05988 & 0.64422 \\
\hline $17: 00$ & 0.1094 & 0.912 & 0.0635 & 0.1063 & 0.015156 & 0.198864 \\
\hline Average/ & 3.35 & 4.55 & 0.36 & 0.42 & 1.93 & 2.49 \\
\hline Day & & & & & 21.94 & 29.86 \\
\hline Wh / Day & & & & & & \\
\hline
\end{tabular}

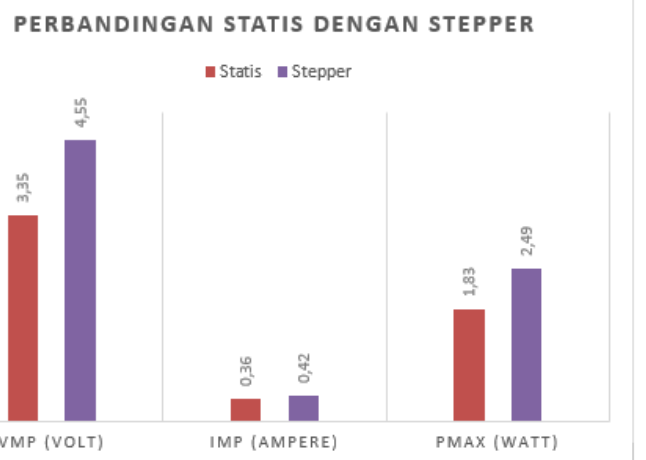

Gambar 5. Perbandingan Solar Panel statis dengan dinamis (Stepper)

Dari grafik pada gambar 5 dapat dilihat besar tegangan yang didapatkan oleh solar panel pada posisi tetap lebih kecil bila dibandingkan oleh perolehan solar panel pada posisi mengikuti gerak matahari, dari hasil perhitungan diperoleh rata rata nilai $V_{m p}$ untuk posisi tetap adalah sebesar 3,35 Volt, $I_{m p}$ 0,36 A, $P_{\max }$ 1,83 watt sedangkan pada posisi tracker menggunakan stepper adalah sebesar 4,55 Volt, $I_{m p} 0,42 \mathrm{~A}, P_{\max } 2,49$ watt. Energi pada sistem dinamis (Stepper) $36 \%$ lebih besar daripada statis.

Perbedaan arus antara penggunaan motor servo dan motor stepper terlihat tidak terlalu signifikan, karena keduanya sama-sama mengikuti cahaya matahari, namun pergerakan motor stepper lebih presisi dibandingkan dengan motor servo.

\section{Perhitungan Radiasi Matahari}

Tabel 3. Perhitungan radiasi matahari

\begin{tabular}{|c|c|c|c|}
\hline Waktu/15 & \multicolumn{3}{|c|}{ Radiasi Matahari (Lux) } \\
\cline { 2 - 4 } $\begin{array}{c}\text { Menit } \\
\text { (HH.MM) }\end{array}$ & Statis & Servo & Stepper \\
\hline $6: 00$ & 358.25 & 508.25 & 509 \\
\hline $7: 00$ & 358.5 & 476 & 477.5 \\
\hline $8: 00$ & 635 & 696.5 & 698.25 \\
\hline $9: 00$ & 841.5 & 877.5 & 878.5 \\
\hline $10: 00$ & 897.5 & 897.5 & 898.5 \\
\hline $11: 00$ & 730.5 & 730.5 & 732 \\
\hline $12: 00$ & 777.75 & 852 & 852.25 \\
\hline $13: 00$ & 640.25 & 725.5 & 724.75 \\
\hline $14: 00$ & 526.75 & 735 & 736.75 \\
\hline $15: 00$ & 437.75 & 649.25 & 644.5 \\
\hline $16: 00$ & 233.95 & 425.25 & 425.7 \\
\hline $17: 00$ & 180.79 & 333.65 & 334.54 \\
\hline $\begin{array}{c}\text { Average / } \\
\text { Day }\end{array}$ & $\mathbf{5 5 1 . 5 4}$ & $\mathbf{6 5 8 . 9 1}$ & $\mathbf{6 5 9 . 3 5}$ \\
\hline
\end{tabular}


Rata-rata Radiasi Matahari / hari

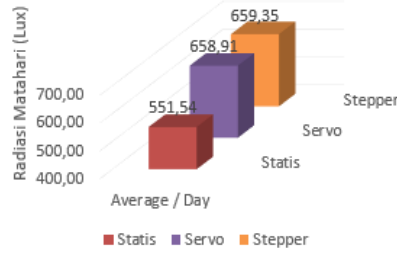

Gambar 6. Rata-rata Radiasi Matahari / hari

Dari grafik pada gambar diatas terlihat radiasi matahari yang diterima oleh solar panel pada posisi tetap lebih kecil bila dibandingkan oleh perolehan solar panel pada posisi mengikuti gerak matahari, dari hasil perhitungan diperoleh rata rata nilai radiasi matahari untuk posisi tetap adalah sebesar 551,54 lux sedangkan pada posisi tracker yang menggunakan motor servo adalah sebesar 658,91 lux dan yang menggunakan stepper adalah 659,35 lux.

\section{KESIMPULAN}

1. Hasil analisa menunjukkan bahwa daya yang diperoleh Solar Panel yang mengikuti pergerakan cahaya matahari (Solar Tracker) lebih besar dibandingkan dengan Solar Panel pada posisi tetap. Produksi energi pada sistem dinamis dengan menggunakan servo 33\% lebih besar dibandingkan dengan statis, sedangkan yang menggunakan stepper 36\% lebih besar daripada solar cell dengan kondisi statis.

2. Mikrokontroler Arduino UNO R3 dapat bekerja dengan baik dalam instruksi program solar tracker.

3. Solar tracker dengan menggunakan motor stepper sebagai kontrolnya lebih efisien dibandingkan dengan yang menggunakan motor servo, hal ini disebabkan oleh pergerakan motor stepper yang lebih presisi atau lebih tepat dalam mengikuti pergerakan cahaya matahari. Efisiensi dari Solar Cell dengan motor servo sebesar $4,09 \%$, efisiensi dengan motor stepper sebesar 4,19\% sedangkan pada posisi tetap efisiensinya adalah sebesar $3,68 \%$.

\section{UCAPAN TERIMA KASIH}

Penyusunan penelitian ini melibatkan beberapa pihak, untuk itu saya ucapkan terima kasih kepada :

1. Bapak Dr. Ing. Oo Abdul Rosyid, MSc

2. Bapak Syaiful Bakhri, S.T., M.Eng.Sc., Ph.D.

3. Bapak Seflahir D., S.T., M.Pd.T.

4. Nur Abdi Insani, ST, MT

\section{REFERENCES}

[1] Bueche, Frederick J, B. Darmawan, "Fisika Edisi Ketujuh", Jakarta, PT. Erlangga, 1994.

[2] Dalimunthe, Chaeruddin, "Pengkajian Sumber Energi Listrik Alternatif dan Mesin Listrik Alternatif", Bandung, Angkasa, 2003.

[3] Philips, Charles L, Royce D. Harbor, "Sistem Kontrol: Dasar-dasar (Feedback Control Systems, 3e)", Jakarta, PT. Prenhallindo, 1997.

[4] Paul, Hatfield, "Low Cost Solar Tracker", Curtin Department of Electrical and Computer Engineering.

[5] Pujiono. 2013. Rangkaian Listrik. Jakarta: Penerbit Graha IImu.

[6] Berahim, Hamzah., 2011. Teknik Tenaga Listrik Dasar. Jakarta: Penerbit Graha IImu.

[7] Wartiningsih, Tri dan Kholistianingsih dan Atmadi, P.B. 2014. Pembangkit Tenaga Listrik. Jakarta: Penerbit Graha IImu.

[8] Alawiy, M, T., Affandi, S., Fahrulrozi, M. Rekayasa Peningkatan daya Pembangkit Listrik Tenaga Surya Perumahan Dari Daya 50 Watt Menjadi 1000 Watt. 2015.

[9] Sanjaya, Mada WS. 2013 Membuat Robot Bersama Profesor Bolabot. Yogyakarta: Penerbit Gava Media.

[10] Jurnal Fisika Unand Vol. 4, No. 2, April 2015 ISSN 2302-8491.

[11] Jurnal Keteknikan Pertanian Tropis dan Biosistem, Vol. 1 No. 1, Februari 2013, 55-59.

[12] PROYEKSI POTENSI ENERGI SURYA SEBAGAI ENERGI TERBARUKAN, Deni Septiadi, 
Pieldrie Nanlohy, M. Souissa dan Francis Y. Rumlawang. ISSN : 1411-3082.

[13] S. Nema, R. K. Nema, G. Agnihotri, Matlab/Simulink Based Study of PhotovoltaicCells/ Modules/ Array and Their Experimental.

[14] Rancang bangun solar tracking system untuk mengoptimalkan penyerapan energi matahari pada solar cell, Wasana Saputra, FT UI, 2008. 